\title{
Study on the Strategies of Improving Employment Core Competitiveness of English Major Graduates in Independent College
}

\author{
Xiang Zhang \\ English Department \\ China University of Geosciences Great Wall College \\ Baoding, China
}

\begin{abstract}
With the rapid de velopment of China's higher education, the number of university graduates expanded rapidly. At the same time, employment competition is becoming increasingly fierce and the employment situation for independent college students becomes more optimistic, especially for English majors. The expansion of enrollment and "red card" major, graduates are faced with the heavy pressure of employment. How to enhance their core competence of employment has become the top priority of independent college students and education management.
\end{abstract}

Keywords-core competence; English Majors; independent college; strategy

\section{INTRODUCTION}

The current employment situation is becoming more and more serious and the employment competition is becoming increasingly fierceful. The difficulty of employment for the college students has become the focus of attention.Independent college graduates are especially facing more difficult competition environment.In recent years, the "English Hot" makes English graduates oversupply, the quality of major education also declined, resulting in many English major graduates in employment difficulties.To solve the employ ment problem of Independent College English majors, it is necessary to cultivate the employment of their core competencies effectively.

\section{THE CORE COMPETENCE OF EMPLOYMENT OF INDEPENDENT COLLEGE ENGLISH MAJOR GRADUATES}

First, Core Competence was formally introduced by Professor C. K. Prahalad and Gary Hamel of University of Michigan in 1990. It refers to the ability of integration of the knowledge and skills which are formed in the course of business of enterprise to be competitive rivals to follow the concept of "core competencies" bring excess profits unique ability within an organization.

The core competence of employment of university students' is that during the student's education training period, individual students accumulate the formation through the learning purpose and practice. It plays a leading role in the system of ability of college students and enables students to obtain competition advantages and sustainable development in the competition in the job market. It is unique and it is not easy to imitate by others. The core competence of employment is a comprehensive force, not all elements of the simple sum. And for the English majors, the core competence of employment mainly includes the English language professional ability, practical ability of English, job skills and employment resources utilization ability and so on.

Independent college is a kind of second level college held by the Common colleges and Universities under the new mechanism and new pattern and is an exploration and innovation of the mechanism and mode of Higher Education under the new situation. It is difficult to reconcile the contradiction of the number of college enrollment increased sharply and less jobs position caused by the global financial crisis, and also the prejudice and discrimination of the three identity from the employers in the society towards to the independent college graduates and independent college graduates overall quality is not high, In recent years, the overall employ ment rate and quality of the independent college graduates has always been difficult to meet people's expectations.

\section{THE MAIN FACTORS RESTRICTINGTHE EMPLOYMENT CORE COMPETENCE OF ENGLISH MAJORS GRADUATES IN INDEPENDENT COLLEGE}

\section{A. The Weak Basic Skills of English Language and Single Knowledge Structure}

Because of overheating enrollment of the English Majors in latest ten years and "red card" positioning given by the Ministry of Education, the English major graduates are facing severe employment pressure.College entrance examination candidates and their parents are no longer choose English as their majors in the choice of the volunteer, so the independent college students admission scores are getting lower and the quality of students declined.

The English language learning can not be improved overnight and students need a long time hard work and dedication, it should practice again and again. The independent college students' own laziness and the poor self-learning ability 
result in lack of solid basic skills of English language. The basic training of listening, speaking, reading, writing and translating ability is not enhanced, leading directly to the students' English language application ability is low. Many English major graduates can not communicated fluently, write full of mistakes, can not translate well and can not write basic format of English correspondence.

In addition, in the actual employ ment process, the English major graduates once exposed to business, trade, science and technology, law and other fields, they are almost unknown this field. It is difficult to meet the requirements of employers or because they do not understand the professional knowledge and give up jobs. Now many non-English majors attach great importance to English learning, their English is better than English majors, and thus become a strong opponent. So the English graduates in jobs hunting, their English application ability is becoming very limited.

\section{B. Lack of Real Professional Practice and Training Opportunities}

The courses of English majors are main ly basic courses, so the practice and training courses are very weak. The Independent college students are more active, although they participate in many community activities, social part-time jobs (such as salesman, volunteer), tutor, translator; these are broad practice and training. The relationship with the English language is not very close. While the English Majors' professional practice is to solve by the students themselves through contacting practice units. In this way, due to the lack of systematic training and the lack of necessary supervision and guidance, it is difficult to ensure the effectiveness of practice.

\section{Employment Targets Are Not Very Clear and the Formation of Employment Consciousness is Late}

When the English majors in the independent college choosing a career, they lack of the goal and are unable to establish a clear employment direction. The formation of student's employment consciousness is late, so they lack of clear understanding of the professional and employment prospects. In the actual employment process, due to the discrimination of the identity of the independent college students, expectation value of a large number of students engaged in English related occupational is very low. So these let them suffer varying degrees of combat in the course of employ ment. In addition, the development of our independent college employ ment guidance work is not long, the theoretical research and practical experience is still lacking, all of these are not adapt to the independent college students' practical needs. These also lead to the low employment of the independent colleges graduates.
IV. THE STRATEGIES OF IMPROVINGTHE INDEPENDENT COLlege ENGLISH MAJOR GRADUATES' CORE COMPETENCE OF EMPLOYMENT

\section{A. Strengthen the Basic Skills of English Language Training and Enhance the Core Competitiveness}

Professional quality has become an important factor to measure college students. For English majors, the basic skills of English language are the essence of their professional qualities, and also the core and key of College Students' employ ment. Due to the self-discipline ability of independent college students is bad, so the teachers need proper guidance and real-time supervision. During the period of learning, The English major undergraduates must cherish every opportunity to enhance their listening, speaking, reading, writing and translating ability, laying a solid foundation of professional and actively participate in the interaction in classroom teaching and extracurricular activity time and continue to strengthen the actual ability to use English language.

\section{B. Optimize the Curriculum and Highlight the Oral Courses}

Graduates' comprehensive quality varies greatly, especially the poor oral English level, so it cannot meet the demand of the employers. That is the common problem encountered in English major graduates in the employment. Oral English level is the most important factor for successful candidates. The construction of distinctive English major courses especially for independent college English major courses and it do not rigidly adhere to the fixed pattern, but highlight the characteristics of their own. Therefore, the curriculum should increase the proportion of oral English class and fluent in oral English will be as the primary goal of training.

Social demand for English majors has been from "single" of the past to the "compound" talent of international exchanges and cooperation. It expanses into the field of international trade, finance, economy, technology, business management, ecommerce, secretarial and other complete English communication system. To further expand the English teaching space, according to the students' interests and hobbies It should strengthen the application of computer, text processing, economic and financial knowledge training for English majors and expand the knowledge of English major students and create a composite English talent.

Text heads organize the topics on a relational, hierarchical basis. For example, the paper title is the primary text head because all subsequent material relates and elaborates on this one topic. If there are two or more sub-topics, the next level head (uppercase Roman numerals) should be used and, conversely, if there are not at least two sub-topics, then no subheads should be introduced. Styles named "Heading 1," "Heading 2," "Heading 3," and "Heading 4" are prescribed.

\section{Strengthen Practical Training and School Enterprise Cooperation}

Through increasing practice curriculum, they can strengthen students' vocational skills training, expand training base, let the students learn professional. not only stick to the classroom, but also combine theory with practice and 
professional learning and market demand integration. It can deepen the students learn knowledge, improve their practical ability.

\section{Increase Employment Guidance and Correct the Attitude of Students toward Employment}

The employ ment pressure of English majors is increasing, so the teacher's guidance on the employment of graduates is very important. First of all, to guide students to understand more about English majors, and let the students understand the courses of learning and master skills, which are closely related work in the future so as to mobilize the enthusiasm of students learning English language. To make clear the requirements of the English majors and let the students establish the employment direction and the employment target earlier. Secondly, to guide students to understand the national employment policy and employment situation of today's society. To make clear with the requirements of the overall quality of graduates and professional quality, so as to carry out employ ment guidance, and help students establish the correct employ ment view. Graduates should not be blindly staring at big cities, they should lower their employment expectations, consider employment of low level, required less basic job experience, to accumulate the relevant work experience and improve the ability to practice.

\section{CONCLUSION}

China's higher education has been turning from "elite education" to "mass education", so the graduates of English majors no longer are the social elite, but ordinary workers. Independent colleges should help the students to establish a correct concept of employment, strengthen professional education at the same time, guide students to understand the professional characteristics, form the self-career attitudes, strengthen vocational training and guidance, take various measures and improve the employment competitiveness of students majoring in English. At the same time, students should actively face the market challenge, establish confidence in employment, in order to truly improve the English Major Graduates Employ ment Core Co mpetence.

\section{REFERENCES}

[1] Zhang Z.H, "On the strategies and training of English Majors' employment core competence in newly built Universities" Shanxi Jiaoyu Gaojiao. Xi'an, vol. , pp. 68-69, March 2012.

[2] Lai Z, "Ten Core Competent Factors for Egnlsih Majors in Chinese University "Foreign Language and Literature. Beijing, vol.25 , pp. 128132, October 2009.

[3] Lai Z, "Strategies for improving the core competitiveness of College English Majors' Employment" China Adult Education. Shan Dong, vol. 25 , pp. 65-66, October 2010 